\title{
Reproductive phenology of Miconia mirabilis (Melastomataceae) within three distinct physiognomies of Atlantic Forest, Bahia, Brazil
}

\author{
Michaele de Souza Pessoa ${ }^{1,2,3,4,5}$, Kristel Myriam De Vleeschouwer ${ }^{1,2}$, Daniela Custódio Talora ${ }^{3}$, \\ Larissa Rocha ${ }^{2,3}$ \& André Márcio Araújo Amorim ${ }^{3,4}$ \\ ${ }^{1}$ Center for Research and Conservation, Royal Zoological Society of Antwerp, Koningin Astridplein 26, \\ B-2018 Antwerpen, Belgium. www.university-directory.eu \\ ${ }^{2}$ Instituto de Estudos Socioambientais do Sul da Bahia - IESB, Rua Araújo Pinho, 72, $3^{\circ}$ andar, \\ CEP 45653-145, Ilhéus, BA, Brazil. www.iesb.org.br \\ ${ }^{3}$ Universidade Estadual de Santa Cruz - UESC, Rodovia Ilhéus, Itabuna, Km 16, \\ CEP 45650-000, Ilhéus, BA, Brazil. www.uesc.br \\ ${ }^{4}$ Herbário CEPEC/CEPLAC, Rodovia Ilhéus, Itabuna, Km 22, CEP 45650-000, Ilhéus, BA, Brazil \\ ${ }^{5}$ Corresponding author: Michaele de Souza Pessoa, e-mail: michaelepessoa@gmail.com
}

PESSOA, M.S., VLEESCHOUWER, K.M., TALORA, D.C., ROCHA, L.\& AMORIM, A.M.A. Reproductive phenology of Miconia mirabilis (Melastomataceae) within three distinct physiognomies of Atlantic Forest, Bahia, Brazil. Biota Neotrop. 12(2): http://www.biotaneotropica.org.br/v12n2/en/abstract?article+bn01112022012

\begin{abstract}
Although Miconia mirabilis is a very common species in disturbed forest areas and is known for providing food resources for the local fauna, little is known about its reproductive phenology and other ecological aspects. The present study compares intra- and inter-annual patterns in the reproductive phenophases of that species in three distinct physiognomies of Atlantic Forest in Southeastern Bahia based on semi-quantitative observations conducted over a period of three years. We searched for possible relationships with climatic variables, differences among sites and synchrony. Both the flowering and fruiting strategies of M. mirabilis were classified as annual extended in all three study sites. We found no significant differences among years. Despite low seasonality of the regional climate, intensities of the different phenophases were negatively correlated with day length and temperature. In general, inter- and intra-population synchrony for flowering and fruiting was high (between 0.65 and 0.78), except for inundated forest, probably due to the stress caused by flooding. Given that Miconia mirabilis has the potential to be an important food resource for the local fauna due to the large quantities of flowers and fruits produced and their almost year-round availability, and its capacity for occupying impoverished areas, the species may be considered in restoration programs as a potentially interesting species capable of attracting frugivores to disturbed areas.
\end{abstract}

Keywords: flowering, fruiting, pioneer species, secondary forest.

PESSOA, M.S., VLEESCHOUWER, K.M., TALORA, D.C., ROCHA, L. \& AMORIM, A.M.A. Fenologia reprodutiva de Miconia mirabilis (Melastomataceae) em três fisionomias distintas na Floresta Atlântica, Bahia, Brasil. Biota Neotrop. 12(2): http://www.biotaneotropica.org.br/v12n2/pt/abstract?article+bn01112022012

Resumo: Apesar de Miconia mirabilis ser uma espécie comum em áreas de floresta perturbada e conhecida por fornecer recursos alimentares para a fauna local, pouco se sabe sobre sua fenologia reprodutiva e outros aspectos ecológicos. O presente estudo teve como objetivo comparar os padrões intra e interanual das fenofases reprodutivas da espécie em três fisionomias distintas de Floresta Atlântica no sudeste da Bahia com base em observações semi-quantitativas, realizadas num período de três anos. Também procurou por possíveis relações com as variáveis climáticas, diferenças entre os locais e sincronia. Ambas as estratégias, floração e frutificação, de M. mirabilis foram classificadas como anuais estendidas em todos os três locais de estudo. Não houve diferenças significativas entre os anos. Apesar do clima regional apresentar baixa sazonalidade, as intensidades das diferentes fenofases foram negativamente correlacionadas com o comprimento do dia e temperatura. Em geral, a sincronia inter e intra populacional para a floração e frutificação foi alta (entre 0,65 e 0,78), exceto para a floresta inundada, provavelmente devido ao estresse causado pelo solo alagado. Assim, Miconia mirabilis tem potencial de ser um importante recurso alimentar para a fauna local, devido a grande quantidade de flores e frutos produzidos, sua disponibilidade quase o ano todo, e por ocupar áreas empobrecidas, a espécie pode ser considerada potencialmente interessante em programas de restauração e capaz de atrair animais frugívoros em áreas perturbadas.

Palavras-chave: floração, frutificação, espécies pioneiras, floresta secundária. 


\section{Introduction}

Variations in the reproductive phenology of plant species are influenced by proximate environmental traits - such as precipitation, temperature and radiation - that initiate reproductive phases, and modulated by ultimate factors that select for particular reproductive phenologies, such as pollinators, seed dispersers, and predators (Adler \& Kiepinski 2000, Ramos \& Santos 2005). The heterogeneity of reproductive patterns within a given population may also be related, however, to differences in microhabitats (Newstrom et al. 1994), to floristic and/or edaphic variations between nearby tropical forest areas (Heideman 1989) or to periodic environmental disturbances such as flooding during the rainy season (Satake et al. 2001, Haugaasen \& Peres 2005).

Reproductive patterns may further be influenced by successional stage and habitat differences both at community (Kang \& Bawa 2003, Andreis et al. 2005) and population (Roos \& Quinn 1977, Williams-Linera 2003) levels, and can be altered by fragmentation (Fuchs et al. 2003, Laurance et al. 2003). As such, the intensity and synchrony of reproductive phenophases may be associated with competition for light (Levey 1990, Siemann \& Rogers 2003, Laurance et al. 2003, Fuchs et al. 2003, Ramos \& Santos 2005) or even with limitations imposed on/by pollinators and dispersers (Rocha \& Aguilar 2001, Calabrese \& Fagan 2004, Borchert et al. 2005).

Synchrony of phenological events among individuals indicates their adaptation to abiotic or biotic factors (Van Schaik et al. 1993) that presumably confer adaptive advantages to these plant species (Pedroni et al. 2002). This may be a response to environmental conditions in tropical seasonal forests, which can synchronize flowering in the dry season (Muniz 2008, Coelho \& Machado 2009) or in the beginning of rainfalls (Mori \& Pipoly 1984, Santos et al. 2010). Also, environmental stress due to fire (Sarmiento 1992, Munhoz \& Felfili 2005) or flooding (Spina et al. 2001, Aragão et al. 2005) can contribute to synchronize reproductive phenophases. Otherwise, interactions between biotic factors may lead either to the minimization or maximization of phenological overlap among plant species (Van Schaik et al. 1993), resulting in fitness advantages through cross-pollination, attracting dispersers and satiating seed predators (Augspurger 1981, Corlet 1990, Thies \& Kalko 2004, Franklin \& Bach 2006) or, in the case of asynchrony, by promoting "outcrossing" between distant plants (IMS 1990). Thus, the timing, duration and degree of synchrony of different phenophases within a plant population will therefore determine the availability of resources to associated fauna (Williams et al. 1999).

Melastomataceae comprises more than 4,500 species and 150 genera from tropical and subtropical areas in both Old and New Worlds (Renner 1993). This family is considered important for sustaining frugivore diversity in tropical forests (Stiles \& Rosselli 1993, Manhães et al. 2003). Miconia Ruiz \& Pavon is the largest genus in the family and probably one of the richest genera of flowering plants in the New World (Goldenberg et al. 2008). It occurs mainly in secondary areas, at forest edges and in clearings, and it comprises many pioneer species (Schupp et al. 1989, Denslow et al. 1990, Ellison et al. 1993). These plants produce large quantities of resources that are consumed by birds and mammals (Levey 1990, Poulin et al. 1999, Catenacci et al. 2009, Parrini \& Pacheco 2011) and they are considered key-resources for many different frugivore species in tropical communities in Central and South America (Galetti \& Stoltz 1996, Poulin et al. 1999, Peres 2000, Parrini \& Pacheco 2011).

The majority of species from the genus Miconia present annual reproductive patterns (Snow 1965, Hilty 1980, Mori \& Pipoly 1984, Mantovani et al. 2003, Pereira \& Mantovani 2007), however, biannual, annually extended and continuous have also been described, (Levey
1990, Williams-Linera 2003). Some studies indicate variation in the reproductive patterns of this genus in regions with a tropical seasonal climate (Mori \& Pipoly 1984, Williams-Linera 2003, Aragão et al. 2005, Kessler-Rios \& Kattan 2012), with precipitation indicated as the most important influencing factor. In forests with low climatic seasonality, where water is available all year long, photoperiodic changes may induce flowering patterns (Borchert et al. 2005). Responses of plants to higher levels of light intensity can lead to increased production of resources and synchrony in different types of forests (Levey 1990, Williams-Linera 2003).

The species studied here, Miconia mirabilis (Aublet) L.O. Williams, is characteristic of newly regenerating forest areas in southeastern Bahia State (Martini \& Santos 2007), even occurring in areas recovering from fire and pastures. It grows at high densities and dominance levels in secondary forests in intermediate stages of regeneration, and can also be found in other physiognomies, such as advanced secondary and inundated forests although in lower densities (M. S. Pessoa, unpublished). However, it is rare in mature forests (Pessoa 2008, Piotto et al. 2009). Its large production of both flowers and fruits throughout the year (Pessoa 2008) associated with its recent indication as an important food resource for the endangered goldenheaded lion tamarin (Leontopithecus chrysomelas (Kuhl 1820)) indicate that $M$. mirabilis is important in regenerating areas (Catenacci 2008, Catenacci et al. 2009). Although the species is common in the region and may occur in distinct physiognomies providing important resources for local fauna, little is known about its reproductive patterns and whether these vary in different physiognomies.

Our study aims to investigate the potential of Miconia mirabilis for offering food resources in different physiognomies in a forest with low climatic seasonality. Specifically, we addressed the following questions related to both flowering and fruiting: What is the phenological reproductive pattern of the species? Does this pattern vary in the different physiognomies over different years? Which physiognomy has the higher synchrony values? Are its reproductive phenophases correlated with the climate? The answers to these questions allow for evaluating the temporal availability and spatial distribution of food resources of this species in different physiognomies.

\section{Materials and Methods}

\section{Study area}

The present study was conducted in a remnant of Atlantic Forest, within the Una Biological Reserve (Rebio Una) with nearly 19.000 ha $\left(15^{\circ} 10^{\prime} \mathrm{S}\right.$ and $\left.39^{\circ} 03^{\prime} \mathrm{W}\right)$, located in southern Bahia, Brazil. It includes two vegetation types typically found along Brazilian coast: lowland tropical moist forest (tabuleiro forest) and submontane tropical moist forest (Amorim et al. 2008). In general, the study site is a regional forest mosaic composed essentially of tabuleiro forest in different stages of regeneration, interspersed with abandoned pastures and plantations.

We studied the reproductive patterns of $M$. mirabilis in three physiognomies; two successional stages of Atlantic Forest (advanced and medium secondary) and inundated forest. Advanced secondary forest areas suffered logging 30 years ago, and are characterized by trees generally between 15 and $20 \mathrm{~m}$ height, numerous species of Myrtaceae and Sapotaceae and the presence of bromeliads and vines. Medium secondary forest areas had been disturbed by slash-and-burn agriculture and pasture, at least 10 years before our study began. Tree height is generally less than $15 \mathrm{~m}$ height, with open canopy and lots of light entering, with predominance of the Melastomataceae family and lacking bromeliads or vines. Inundated 
forest occurs in areas that suffer from periodic flooding, where the soil is permanently sodden. The canopy is closed, and tree height is generally between 15 and $20 \mathrm{~m}$, similar to advanced secondary forest. This physiognomy contains species typical for swamp forest, such as Symphonia globulifera L.f.

The regional climate is classified as type $A f$ in the Köppen system: humid and hot and characterized by the absence of a defined dry period (Gouvêa et al. 1976). The annual average rainfall is approximately 2,000 $\mathrm{mm}$ (Mori et al. 1983) and it tends to be evenly distributed throughout the year. Average temperatures in the region are high, with values around $24^{\circ} \mathrm{C}$ and little variation during the year. Average summer temperatures can reach up to $26{ }^{\circ} \mathrm{C}$ (Instituto... 1997). Day length reaches its maximum duration (12 to 13 hours) between Sep and Mar, with the shortest days occurring between May and Aug ( 11 hours and 15 minutes). Although precipitation levels in southern Bahia are not as high as those observed in other regions of the Atlantic Forest, this area is notable for the absence of significant seasonal climatic variations (Martini \& Santos 2007).

The amount of rainfall during the study period (Feb 2005 through Jan 2008) was generally near or above average, with the highest precipitation in $2005(2,196 \mathrm{~mm})$ and the lowest in $2006(1,945 \mathrm{~mm})$. The months with highest rainfall rates were Jun 2005 (298 mm), Mar 2006 (362 mm) and Feb, Mar and Nov 2007 ( 250 mm/month). The average annual temperature was $25{ }^{\circ} \mathrm{C}$, and the months with lowest average minimum temperatures were Jul and Aug $\left(19^{\circ} \mathrm{C}\right)$; the highest temperatures were recorded between Dec and Mar $\left(33{ }^{\circ} \mathrm{C}\right)$ for all three study years. Climatic data were obtained from the Climatological Station of Project BioBrasil, located at the study site, where a commercial min-max thermometer and a TRU-CHEK rain gauge were installed (Figure 1).

\section{Phenological study}

To compare the reproductive phenological patterns of Miconia mirabilis among areas and with the whole community, we conducted systematic sampling using point-center quadrants along nine preestablished $200 \mathrm{~m}$ transects (three in each physiognomies) with central points at $15 \mathrm{~m}$ intervals. We included only arboreal individuals with $\mathrm{DBH} \geq 5 \mathrm{~cm}$. The entire community included 09 transects and 431 individuals, 151 in advanced secondary sites, 139 in medium secondary sites, and 141 in inundated forest site. Phenological data were collected simultaneously for community and for M. mirabilis. Initially, we found 74 individuals of the species along these transects, but the number of individuals observed had diminished to 70 by 2008 due to the death of four plants in the inundated forest site. Thus, seven individuals were monitored in advanced secondary forest (4.6\% of the total number of individuals in this area), 56 in medium secondary forest (39.7\% of the total), and eleven (years 2006 and 2007 ) to seven (2008) in the inundated forest site ( 7.1 and $5.1 \%$ of the total respectively).

The trees were visited monthly between Feb 2005 and Jan 2008 (36 months) and the following reproductive phenophases were recorded: 1) flowering: distinguishing buds and anthesis, and 2) fruiting: distinguishing unripe and ripe fruits. We used the Fournier scale (Fournier 1974) to quantify the intensity of each phenophase, both for the community and the population studied. We classified the flowering and fruiting strategies of Miconia mirabilis in the different physiognomies according to Newstrom et al. (1994)

\section{Statistical analysis}

As the data were non-parametric, we used Spearman Rank Correlations to test for correlations between the monthly activity indices of each phenophase and the different meteorological variables of the same month (rainfall, average temperature and day length) over the three year period. Since there can be a delay between changes in climatic conditions and the triggering of plant responses, we also checked for correlations between a given phenophase activity and the climatic data of the previous month. We used Kruskal-Wallis test to verify if there were significant differences in the mean annual values of intensity for each phenophase (flower buds, anthesis, unripe and ripe fruits) among sites and among the three years studied. When the Kruskal-Wallis test detected a significant difference, the Dunn test was performed to compare pairs of sites and years. All analyses were performed using the Bioestat 5.0 and Past 2.03 program.

We used the method proposed by Augspurger (1983) to determine the degree of synchrony of each phenophase, in which individual flowering and fruiting synchronies are measured as the relative overlap between the phenophase period of a given individual and all of the others in that population. Inter- and Intra-population synchrony was calculated in general and within each area of occurrence of the focal species (inundated forest, advanced and medium secondary forest).

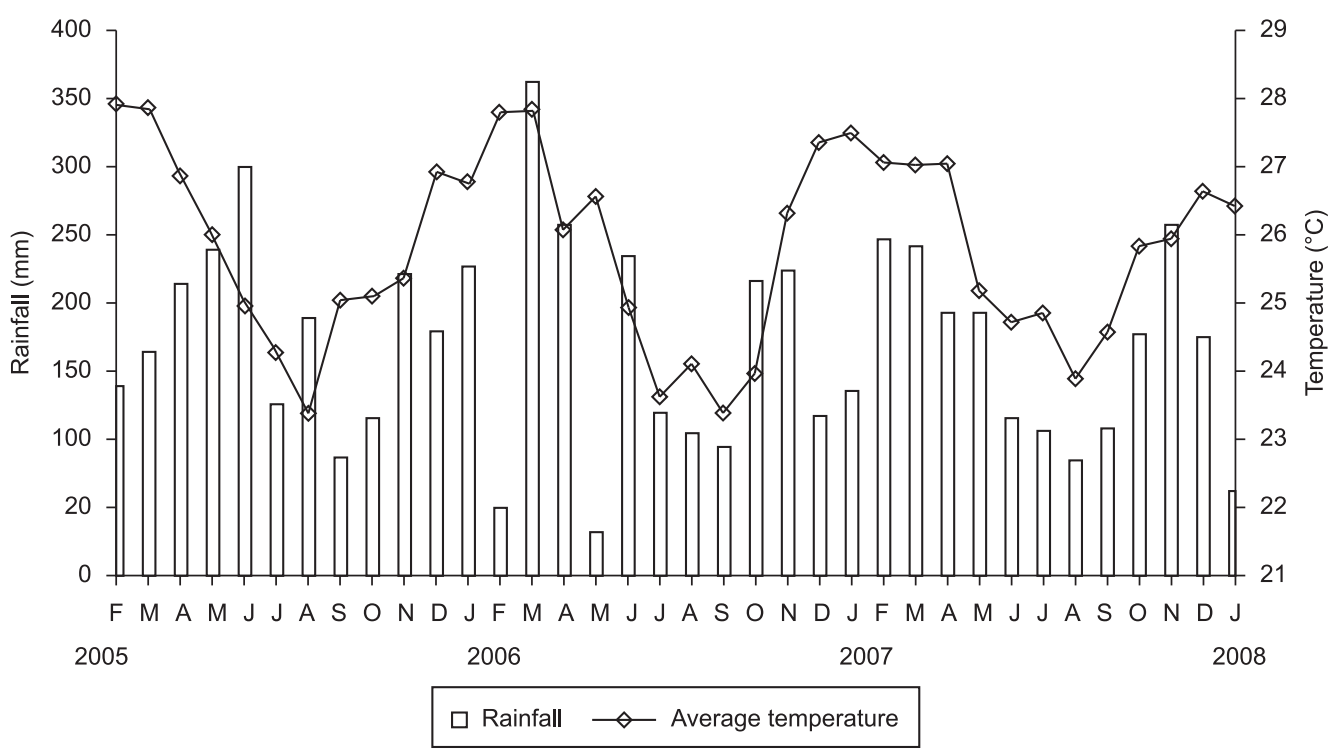

Figure 1. Precipitation and average temperature at the study site in the Una Biological Reserve, Bahia State, Brazil, from February 2005 through January 2008. Source: Project BioBrasil. 


\section{Results}

\section{Spatial variation}

The resources produced by Miconia mirabilis (Figure 2) had a significant impact on the community as a whole, representing more than $80 \%$ of the total of flowers offered in some months, and up to $74 \%$ of fruits (Figure 2a). These high levels were typical for medium secondary forest, where the species predominated. Also, flowering and fruiting intensity was higher for the population in medium secondary (Figure 2b) as compared to the other physiognomies (Figure 2c, d), for all phenophases (Table 1). Considering the advanced secondary forest areas and inundated forest environments (where this species is less abundant) separately (Figure 2c, d), these community patterns as a whole did not show dependence on the resources produced by $M$. mirabilis, both for flowers and fruits. In the medium secondary forest (Figure $2 \mathrm{~b}$ ), however, where $M$. mirabilis predominates, the general pattern of the community is intimately linked to the abundance of the resources produced by that species.

\section{Temporal variation}

Comparisons among years showed no significant differences in flowering intensities for medium and advanced secondary forest (Table 2). The inundated forest differed from the others, showing significant differences for anthesis but no significant differences in budding. Otherwise, the comparison of fruit production among years showed no significant differences for all physiognomies (Table 2). The reproductive strategy of $M$. mirabilis was considered annual extended in the three sites (Figure 2b-d), showing a continuous pattern in 2005 and 2007 in the medium secondary forest (Figure 2b), and in 2005 in the inundated forest area (Figure 2d). The highest flowering intensities were observed between May and Aug in all three physiognomies, although with interannual variations in each area (Figure $2 b-d$ ). The flowering patterns were more similar between years in the medium secondary forest than in the other sites. The highest levels of fruiting occurred from Jul through Nov in 2005 and 2006, and from Apr to Sep in 2007, with variations in the intensities at all sites. The unripe fruit production was consistently higher than ripe fruits during the entire period in all three physiognomies.

Miconia mirabilis flowers and fruits are generally available (although at low intensities) at the medium secondary site even during months of resource scarcity. This situation was observed, for example, for flowering in Oct 2006 and for fruiting in Dec 2006 and Jan 2007 (Figure 2b). Intrapopulational synchrony was high for flowering and fruiting in the medium secondary and advanced secondary physiognomies, but not in the inundated forest. Interpopulation synchrony was high for all phenophases (Table 3 ).

\section{Correlation with climatic variables}

Flowering was negatively correlated to day length in all sites both for the same and the previous month, with decreasing levels of bud production and floral anthesis corresponding to increases in day length. In general, no correlations were observed between flowering with precipitation and temperature. Fruiting was also negatively related to day length of the previous month, with increasing production of unripe and ripe fruits corresponding to decreasing in day length at all sites. Only the production of ripe fruits in the medium secondary site was not correlated with the day length of the previous month. Fruiting in $M$. mirabilis was also inversely related to the average temperature for both the previous and the same months, in all sites. Thus, lower temperatures were correlated with increased productions of unripe and ripe fruits in the three physiognomies studied (Table 4).

\section{Discussion}

The predominant flowering and fruiting pattern observed for Miconia mirabilis was annual extended in all three physiognomies, with flower and fruit production being interrupted for only one to just a few months a year. The presence of these abundant resources throughout the year clearly influenced the general pattern of the community. Continuous and extended reproductive patterns mean year-round food availability for pollinators and frugivores, and this in turn contributes to community maintenance through the constant presence of the animals using those resources (Snow 1965, Denslow et al. 1986, Pedroni et al. 2002, Bolmgren et al. 2003, Boulter et al. 2006, Elzinga et al. 2007).

Even though $M$. mirabilis showed similar flowering and fruiting patterns in all three physiognomies it was more intense in the medium secondary site. This may have been due to the increased amount of light available in these early succession sites where tree crowns are more widely spaced. High light intensity conditions generally generate bigger flowering events (Mori \& Pipoly 1984, Van Schaik et al. 1993, Wright \& Van Schaik 1994) and fruit production (Denslow et al. 1986, Galetti \& Stoltz 1996, Levey 1990, Elisson et al. 1993, Rocha

Table 1. Comparison of phenophase intensities among physiognomies: (AS) advanced secondary; (MS) medium secondary and (IF) inundated forest (Kruskal-Wallis H and Dunn Z tests) in the Una Biological Reserve, Bahia State, Brazil.

\begin{tabular}{lcccc}
\hline & Kruskal- & \multicolumn{3}{c}{ Dunn (Z) } \\
\cline { 3 - 5 } & wallis (H) & AS $\times$ MS & AS $\times$ IF & MS $\times$ IF \\
\hline Flower buds & $42.94 *$ & $6.06 * *$ & 0.88 & $5.18 * *$ \\
Anthesis & $39.97 *$ & $5.72 * *$ & 0.55 & $5.18 * *$ \\
Unripe fruits & $43.74 *$ & $6.43 * *$ & 1.90 & $4.54 * *$ \\
Ripe fruits & $23.87 *$ & $4.88 * *$ & 2.26 & $2.62 * *$ \\
\hline
\end{tabular}

$* \mathrm{p}<0.01 ; * * \mathrm{p}<0.05$ significant.

Table 2. Comparison of phenophase intensities over three consecutive years for the physiognomies: (AS) advanced secondary; (MS) medium secondary and (IF) inundated forest (Kruskal-Wallis $\mathrm{H}$ and Dunn $\mathrm{Z}$ tests). The sequence of $\mathrm{Z}$-values refers to the comparisons between the years 1 and 2 (a); 1 and 3 (b); 2 and 3 (c), respectively in the Una Biological Reserve, Bahia State, Brazil.

\begin{tabular}{|c|c|c|c|c|c|c|}
\hline & \multicolumn{3}{|c|}{ Kruskal-wallis (H) } & \multicolumn{3}{|c|}{ Dunn (Z) } \\
\hline & AS & MS & IF & $\mathbf{a}$ & $\mathbf{b}$ & c \\
\hline Flower buds & 0.46 & 1.91 & 4.3 & & & \\
\hline Anthesis & 1.15 & 2.23 & $9.14 *$ & $2.7 * *$ & 0.3 & $2.4 * *$ \\
\hline Unripe fruits & 1.52 & 1.3 & 0.96 & & & \\
\hline Ripe fruits & 0.1 & 0.03 & 0.32 & & & \\
\hline
\end{tabular}

$* \mathrm{p}<0.01 ; * * \mathrm{p}<0.05$ significant.

Table 3. Synchrony values within Miconia mirabilis populations for the phenophases examined at the three different physiognomies in the Una Biological Reserve, Bahia State, Brazil.

\begin{tabular}{lcccc}
\hline \multirow{2}{*}{ Phenophases } & \multicolumn{4}{c}{ Individuals } \\
\cline { 2 - 5 } & $\begin{array}{c}\text { Advanced } \\
\text { secondary }\end{array}$ & $\begin{array}{c}\text { Medium } \\
\text { secondary }\end{array}$ & $\begin{array}{c}\text { Inundated } \\
\text { forest }\end{array}$ & $\begin{array}{c}\text { All } \\
\text { sites }\end{array}$ \\
\hline Flower buds & 0.67 & 0.74 & 0.25 & 0.67 \\
Anthesis & 0.70 & 0.72 & 0.23 & 0.65 \\
Unripe fruits & 0.65 & 0.78 & 0.38 & 0.73 \\
Ripe fruits & 0.65 & 0.71 & 0.23 & 0.72 \\
\hline
\end{tabular}



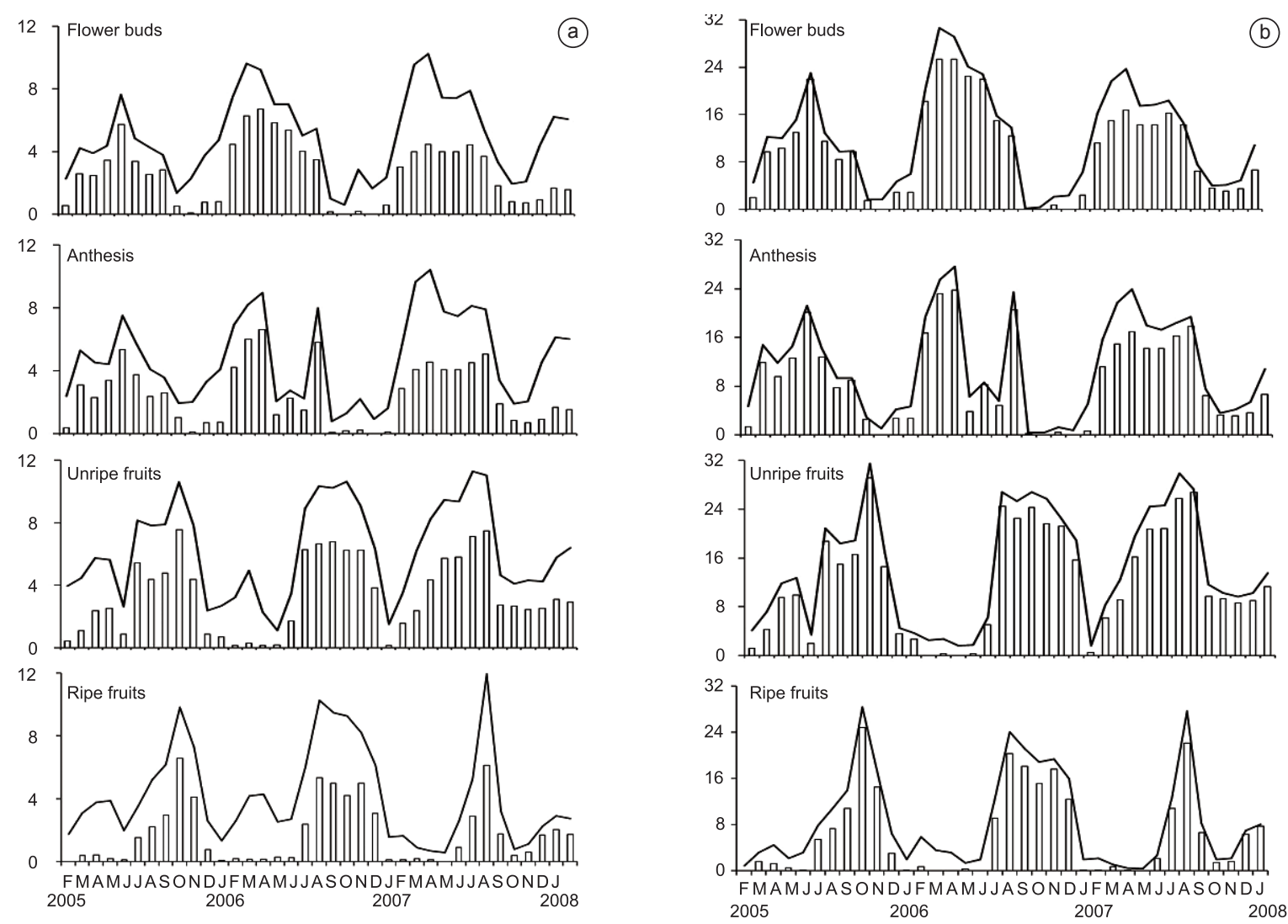

(b)
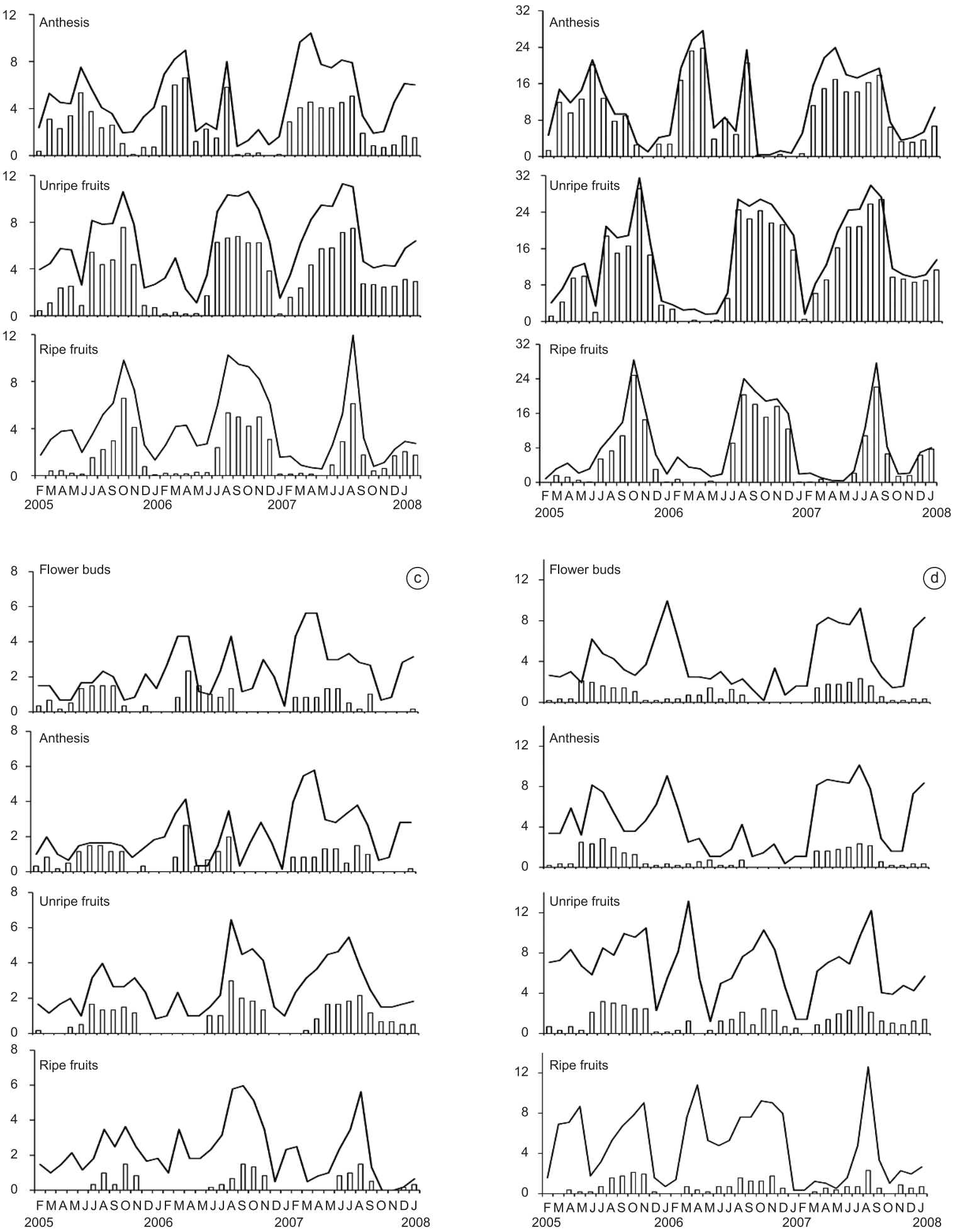

Figure 2. Intensity values of reproductive phenology of the community, compared with Miconia mirabilis, during three years of monthly observations, for the phenophases examined at the three different physiognomies in the Una Biological Reserve, Bahia State, Brazil. The continuous line shows the community pattern including all species surveyed, and is compared to M. mirabilis (bar graphs) in the following areas: (2a) all sites analyzed together; (2b) medium secondary; (2c) advanced secondary and (2d) inundated forest. 
Pessoa, M.S. et al.

Table 4. Spearman rank correlation coefficients between the phenophases and the climatic variables average temperature, precipitation and day length, for the previous $(\mathrm{P})$ and the same $(\mathrm{S})$ month of occurrence in the physiognomies.

\begin{tabular}{|c|c|c|c|c|c|c|c|c|c|c|c|c|c|c|c|c|c|}
\hline & \multicolumn{6}{|c|}{ Advanced secondary } & \multicolumn{6}{|c|}{ Medium secondary } & \multicolumn{5}{|c|}{ Inundated forest } \\
\hline & \multicolumn{2}{|c|}{ Temperature } & \multicolumn{2}{|c|}{ Precipitation } & \multicolumn{2}{|c|}{ Day length } & \multicolumn{2}{|c|}{ Temperature } & \multicolumn{2}{|c|}{ Precipitation } & \multicolumn{2}{|c|}{ Day length } & \multicolumn{2}{|c|}{ Temperature } & \multicolumn{2}{|c|}{ Precipitation } & Day length \\
\hline & (P) & (S) & (D) & (S) & $(\mathbf{D})$ & (C) & $(\mathbf{D})$ & (S) & (D) & (a) & $(\mathbf{D}$ & (S) & $(1)$ & (S) & (D) & (C) & (S) \\
\hline B & 0.00 & -0.27 & 0.27 & 0.03 & * & -0.6 & 0.14 & -0.18 & $0.41 *$ & 0.11 & $1 *$ & & -0.11 & -0.36 & 0.32 & -0.11 & $-0.59 *-1$ \\
\hline AT & -0.04 & -0.32 & 0.10 & 0.01 & $-0.52 *$ & $-0.60 *$ & 0.1 & -0.16 & 0.30 & & $-0.44^{*}$ & $-0.64 *$ & -0.12 & -0.32 & & 10 & $1 *-0.57 *$ \\
\hline JF & $-0.73 *$ & $-0.82 *$ & -0.24 & -0.31 & $-0.70 *$ & -0.41 & $-0.60 *$ & $-0.63 *$ & -0.11 & -0.29 & $-0.57 *$ & -0.29 & $-0.50 *$ & $-0.59 *$ & -0.07 & -0.10 & $-0.56 *-0.39$ \\
\hline $\mathrm{F}$ & $-0.76^{*}$ & $-0.76^{*}$ & -0.39 & -0.42 & $-0.56^{*}$ & -0.22 & $-0.79 *$ & $-0.57 *$ & -0.21 & $-0.48^{*}$ & -0.35 & 0.10 & $-0.68^{*}$ & $-0.71 *$ & -0.25 & -0.23 & $-0.55 *-0.25$ \\
\hline
\end{tabular}

Phenophases: FB- flower buds, AT- anthesis, UF- unripe fruits and RF- ripe fruits in the Una Biological Reserve, Bahia State, Brazil. p < 0.01 significant.

\& Aguilar 2001). Thus the absence of a closed canopy may promote higher levels of flower and fruit production in disturbed environments (Laurance et al. 2003, Martini \& Santos 2007), which seems to be the case for the area studied in Southern Bahia.

Similar patterns were observed in other pioneer species of the genus Miconia in Costa Rica at sites in early stages of succession with open canopies. The colonizing species there produced larger fruit quantities and had longer fruiting episodes than were seen in other individuals of the same species growing under shaded conditions (Levey 1990). This also appears to be the case with M. mirabilis, as it demonstrated more intense flower and fruit production in open areas (medium secondary sites) where more light is generally available.

The individuals demonstrated synchronous flowering and fruiting during several months of the year (although at low intensities during certain periods), except at the inundated site. In fact, flowering (Kang \& Bawa 2003) and fruiting (Levey 1990) duration of early succession species have been observed to be longer than those of climax species. Synchrony in reproductive patterns is common in the genus Miconia, and generally associated with differences in light intensity (WilliamsLinera 2003) or day length (Borchert et al. 2005), as is the case for the species in this study. In inundated areas the species showed less phenological synchronization (between 0.23 and 0.28 ) and intensity (5\%) and the highest mortality (4 individuals, 36\%), indicating that although Miconia mirabilis can colonize such areas, its reproduction and survival are probably affected by water stress. Plant reproduction in this environment may suffer due to stress caused by flooding, as this would limit certain physiological processes (such as root respiration) and thus reduce plant fitness (Satake et al. 2001, Haugaasen \& Peres 2005), and spatial-temporal variations in the flooding regime can influence the responses of the individuals making up the plant population. As such, differences in the quantities of excess water, the duration of flooding, or the location of the individuals could generate different degrees of stress in the population and so interfere with the general reproductive pattern. It is probable that those individuals located in micro-habitats subjected to the longest periods or highest frequencies of flooding will show distinct alterations in the duration and/or intensity of their reproductive events in relation to those individuals subject to less stress - thus generating different patterns within the population and reducing synchrony in those areas.Despite the low climatic seasonality in the study region and the extended flowering and fruiting pattern, we detected a distinct increase in flowering from Mar to Aug and for fruiting from Jul to Nov, related to changes in day length and temperature. We did not find any correlations between flowering and fruiting with precipitation levels in the study areas. In fact, in seasonal tropical forests, the main factor triggering the flowering and fruiting are differences in precipitation (Mori \& Pipoly 1984, Meyer 1998, Aragão et al. 2005, Santos et al. 2010), but in areas with low seasonal climate photoperiod is indicated as the only mechanism that can be attributed to synchronous flowering (Borchert et al. 2005).
The abundance of resources produced by Miconia mirabilis clearly influenced the fluctuations of overall resources available to the faunal community and markedly defined the pattern seen in the medium secondary forest (where it was most prominent). The importance of the resources produced by this species lie not only in the high productivity of the individuals, but also in the great abundance of these plants in altered environments, which guarantees the distribution of these food resources throughout the mosaic of forest and the presence of these resources throughout the year.

Miconia mirabilis demonstrated the greatest production of resources in the community as a whole, contributing up to $98 \%$ of the resources available in the medium secondary forest where it predominated. These regenerating areas, in turn, play an important role in determining the reproductive success of this species, as was described for M. centrodesma in Costa Rica (Levey 1990). Species of the genus are generally present in seed banks, and among the first species to germinate in tropical forest clearings (Ellison et al. 1993, Krijger et al. 1997). As such, a very large proportion of the individuals concentrate their reproductive efforts during the relatively brief period in which this species dominates secondary areas, attracting fauna which will disperse their seeds as they gradually shift to different sites according to the dynamics of forest regeneration.

Miconia mirabilis has the potential to be an important food resource for the local fauna due to the large quantities of flowers and fruits produced and their almost year-round availability (temporal scale), the abundance of this species in anthropogenically altered areas (spatial scale), and because these resources were present during all study years without significant variation in availability (constancy). Considering also that the species is capable of colonizing inundated areas and even areas recovering from fire or pasture, we can suggest it has a high potential to colonize impoverished areas, and may be considered for use in restoration programs as a potentially interesting species capable of attracting frugivores to disturbed areas.

\section{Acknowledgements}

We are grateful to the Center for Research and Conservation of the Royal Zoological Society of Antwerp, Instituto de Estudos Socioambientais do Sul da Bahia (IESB), the Universidade Estadual de Santa Cruz (UESC) and the Herbarium CEPEC/ CEPLAC for providing support to research. We thanks the field assistants José Reis, Antônio, Josinei and the researchers José Lima, Jomar Jardim, Márdel Lopes, Julia Nuscheler, Érica Sá, Lilian Catenacci, Leonardo Oliveira and Luis F. Alberti for various contributions, distinct and specific, during the realization of this work. Thanks to the sponsoring institutions that made this project possible: German Academic Exchange Service (DAAD), Center for Research and Conservation of the Royal Zoological Society of Antwerp, Lion Tamarins of Brazil Fund, National Lottery of Belgium, Conservation International's Primate Action Fund, Zoological Society of London and Ministry of Science of the Flemish Government (Belgium). 
A.M. Amorim is supported by CNPq (Grant 309303/ 2009-5). D.C. Talora received fellowship from $\mathrm{CNPq}$ and funds from FAPESB (DCR 0036/2007). This research was authorized by IBAMA permits $\mathrm{n}^{\mathrm{o}}$ 02001,007626/ 05-85 (M. de S. Pessoa), n 02001,005594/02-31 (K.M. De Vleeschouwer) and MCT n ${ }^{\circ} 195$ (March 25, 2002) (K. M. De Vleeschouwer).

\section{References}

ADLER, G.H. \& KIEPINSKI, K.A. 2000. Reproductive phenology of a tropical canopy tree, Spondias mombin. Biotropica 32:686-692. http:// dx.doi.org/10.1646/0006-3606(2000)032[0686:RPOATC]2.0.CO;2

AMORIM, A.M., THOMAS, W.W., CARVALHO, A.M. \& JARDIM, J.G. 2008. Floristics of the Una Biological Reserve, Bahia, Brazil. In The Atlantic Coastal Forest of Northeastern Brazil (W.W. Thomas, ed.). Memoirs of the New York Botanical Garden, p.67-146.

ANDREIS, C., LONGHI, S.J., BRUN, E.J., WOJCIECHOWSKI, J.C., MACHADO, A.A., VACCARO, S. \& CASSAL, C.Z. 2005. Estudo fenológico em três fases sucessionais de uma floresta estacional decidual no município de Santa Tereza, RS, Brasil. Rev. Árvore 29(1):55-63. http:// dx.doi.org/10.1590/S0100-67622005000100007

ARAGÃO, D.V., FORTINI, L.B., MULKEY, S.S., ZARIN, D.J., ARAUJO, M.M. \& CARVALHO, C.J.R. 2005. Correlation but no causation between leaf nitrogen and maximum assimilation: the role of drought and reproduction in gas exchange in an understory tropical plant Miconia ciliata (Melastomataceae). Am. J. Bot. 92(3):456-461. PMid:21652422. http://dx.doi.org/10.3732/ajb.92.3.456

AUGSPURGER, C.K. 1983. Phenology, flowering synchrony, and fruit set of six neotropical shrubs. Biotropica 15(4):257-267. http://dx.doi. org $/ 10.2307 / 2387650$

AUGSPURGER, C.K. 1981. Reproductive synchrony of a tropical plant: experimental effects of pollinators and seed predators on Hybanthus prunifolius (Violaceae). Ecology 62:775-788. http://dx.doi. org/10.2307/1937745

BOLMGREN, K., ERIKSSON, O. \& LINDER, H.P. 2003. Contrasting flowering phenology and species richness in abiotically and biotically pollinated angiosperms. Evolution 57:2001-2011. PMid:14575322.

BORCHERT, R., RENNER, S.S., CALLE, Z., NAVARRETE, D., TYE, A., GAUTIER, L., SPICHIGER, R. \& VON HILDEBRAND, P. 2005. Photoperiodic induction of synchronous flowering near the Equator. Nature 433:627-629. PMid:15703746. http://dx.doi.org/10.1038/ nature 03259

BOULTER, S.L., KITCHING, R.L.R. \& HOWLETT, B.G. 2006. Family, visitors and the weather: patterns of flowering in tropical rain forests of northern Australia. J. Ecol. 948:369-382.

CALABRESE, J.M. \& FAGAN, W.F. 2004. Lost in time, lonely, and single: Reproductive asynchrony and the Allee effect. Amer. Nat. 164:25-37. PMid:15266368. http://dx.doi.org/10.1086/421443

CATENACCI, L.S., DE VLEESCHOUWER, K.M. \& NOGUEIRAFILHO, S.L.G. 2009. Seed Dispersal by Golden-headed Lion Tamarins Leontopithecus chrysomelas in Southern Bahian Atlantic Forest, Brazil. Biotropica 41:744-750. http://dx.doi.org/10.1111/j.17447429.2009.00530.x

CATENACCI, L.S. 2008. Ecologia alimentar do mico-leão-da-cara-dourada (Primates: Callitrichidae) em áreas degradadas da Mata Atlântica do sul da Bahia. Dissertação de mestrado, Universidade Estadual de Santa Cruz, Ilhéus, Bahia.

COELHO, A.G. \& MACHADO, C.G. 2009. Fenologia reprodutiva de Prepusa montana Mart. (Gentianaceae) em uma área de campo rupestre da Chapada Diamantina, BA, Brasil. Rev. Bras. Bot. 32(2):405-410.

CORLET, R.T. 1990. Flora and reproductive phenology of the rain forest at Bukit Timah, Singapore. J. Tropical Ecol. 6:55-63. CROAT, T. B. 1975. Phenological behavior of habit and habitat classes on Barro Colorado Island (Panama Canal Zone). Biotropica 7:270-277.

DENSLOW, J.S., SCHULTZ, J.C., VITOUSEK, P.M. \& STRAIN, B.R. 1990. Growth responses of tropical shrubs to treefall gap environments. Ecology 71:165-179. http://dx.doi.org/10.2307/1940257
DENSLOW, J.S., MOERMOND, T. \& LEVEY, D.J. 1986. Spatial components of fruit display in understory trees and shrubs. In Frugivores and seed dispersal (A. Estrada \& Fleming, T.H., eds). Dr. W. Junk, The Hague, The Netherlands, p.37-44. http://dx.doi.org/10.1007/978-94-009-4812-9_4

ELLISON, A.M., DENSLOW, J.S., LOISELLE, B.A. \& BRÉNES, D.M. 1993. Seed and seedling ecology of Neotropical Melastomataceae. Ecology 6:1733-1749. http://dx.doi.org/10.2307/1939932

ELZINGA, J.A., ATLAN, A., BIERE, A., GIGORD, L., WEIS, A.E. \& BERNASCONI, G. 2007. Time after time: flowering phenology and biotic interactions. Trends Ecol. Evol. 22:432-439. http://dx.doi.org/10.1016/j. tree.2007.05.006

FOURNIER, L.A. 1974. Un método cuantitativo para la medición de características fenológicas en arboles. Turrialba 24(4):422-423.

FRANKLIN, D.C. \& BACH, C.S. 2006. Assessing intraspecific phenological synchrony in zoochorous trees from the monsoon forests of northern Australia. J. Tropical Ecol. 22(04):419-429. http://dx.doi.org/10.1017/ S0266467406003300

FUCHS, E.J., LOBO, J.A. \& QUESADA, M. 2003. Effects of forest fragmentation and flowering phenology on the reproductive success and mating patterns of the Tropical Dry Forest tree Pachira quinata. Conserv. Biol. 17(1):149-157. http://dx.doi.org/10.1046/j.1523-1739.2003.01140.x

GALETTI, M. \& STOLTZ, D. 1996. Miconia hypoleuca (Melastomataceae) como espécie chave para aves frugívoras no Sudeste do Brasil. Rev. Bras. Biol. 56:435-439.

GOLDENBERG, R., PENNEYS, D.S., ALMEDA, F., JUDD, W.S. \& MICHELANGELI, F.A. 2008. Phylogeny of Miconia (Melastomataceae): patterns of stamen diversification in a megadiverse neotropical genus. Int J. Plant Sci. 169(7):963-979. http://dx.doi.org/10.1086/589697

GOUVÊA, J.B.S., SILVA, L.A.M. \& HORI, M. 1976. Fitogeografia. In Diagnóstico sócio econômico da região cacaueira (Comissão Executiva do Plano da Lavoura Cacaueira e Instituto Interamericano de Ciências Agrícolas, eds.). CEPLAC; IICA, Ilhéus, p.1-10.

HAUGAASEN, T. \& PERES, C.A. 2005. Tree phenology in adjacent Amazonian flooded and unflooded forests. Biotropica 4:620-630. http:// dx.doi.org/10.1111/j.1744-7429.2005.00079.x

HEIDEMAN, P.D. 1989. Temporal and spatial variation in the phenology of flowering and fruiting in a tropical rainforest. J. Tropical Ecol. 77:10591079.

HILTY, S.L. 1980. Flowering and fruiting periodicity in a premontane rain forest in Pacific Colômbia. Biotropica 12(4):298-306.

INSTITUTO BRASILEIRO DO MEIO AMBIENTE E DOS RECURSOS NATURAIS RENOVÁVEIS - IBAMA. 1997. Plano de Manejo - Reserva Biológica de Una - Bahia. p.241.

IMS, R. 1990. The ecology and evolution of reproductive synchrony. Trends Ecol. Evol. 5:135-140. http://dx.doi.org/10.1016/0169-5347(90)90218-3

KANG, H. \& BAWA, K. 2003. Effects of successional status, habitat, sexual systems, and pollinators on flowering patterns in tropical rain forest trees. Amer. J. Bot. 90:865-876. PMid:21659181. http://dx.doi.org/10.3732/ ajb.90.6.865

KESSLER-RIOS, M.M. \& KATTAN, G.H. 2012 Fruits of Melastomataceae: phenology in Andean forest and role as a food resource for birds. J. Tropical Ecol. 28:11-21. http://dx.doi.org/10.1017/S0266467411000642

KRIJGER, C.L., OPDAM, M., THÉRY, M. \& BONGERS, F. 1997. Courtship behaviour of manakins and seed bank composition in a French Guianan rain forest. J. Tropical Ecol. 13:631-636. http://dx.doi.org/10.1017/ S0266467400010774

LAURANCE, W.F., RANKIN-DE MERONA, J.M., ANDRADE, A., LAURANCE, S.G., D'ANGELO, S., LOVEJOY, T.E., HERALDO L. \& VASCONCELOS, H.L. 2003. Rain-forest fragmentation and the phenology of Amazonian tree communities. J. Tropical Ecol. 3:343-347. http://dx.doi.org/10.1017/S0266467403003389

LEVEY, D.J. 1990. Habitat-Dependent fruiting behavior of an understorey tree, Miconia centrodesma, and tropical treefall gaps as keystone habitats for frugivores in Costa Rica. J. Tropical Ecol. 6:409-420. http://dx.doi. org/10.1017/S026646740000479X 
MANHÃES, M.A., ASSIS, L.C.S. \& CASTRO, R.M. 2003. Frugivoria e dispersão de sementes de Miconia urophylla (Melastomataceae) por aves em um fragmento de Mata Atlântica secundária em Juiz de Fora, Minas Gerais, Brasil. Ararajuba 11(2):173-180.

MANTOVANI, M., RUSCHEL, A.R., REIS, M.S., PUCHALSKI, A. \& NODARI, R.O. 2003. Fenologia reprodutiva de espécies arbóreas em uma formação secundária da Floresta Attântica. Rev. Árvore 27:451-458. http://dx.doi.org/10.1590/S0100-67622003000400005

MARTINI, A.M.Z. \& SANTOS, F.A.M. 2007. Effects of distinct types of disturbance on seed rain in the Atlantic forest of NE Brazil. Plant Ecol. 190:81-95. http://dx.doi.org/10.1007/s11258-006-9192-6

MEYER, J. 1998. Observations on the reproductive biology of Miconia calvescens DC (Melastomataceae), an alien invasive tree on the island of Tahiti (South Pacific Ocean). Biotropica 30:609-624. http://dx.doi. org/10.1111/j.1744-7429.1998.tb00101.x

MORI, S.A. \& PIPOLY, J.J. 1984. Observations on the big bang flowering of Miconia minutiflora (Melastomataceae). Brittonia 36:337-341. http:// dx.doi.org/10.2307/2806595

MORI, S.A., BOOM, B.M., CARVALHO, A.M. \& SANTOS, T.S. 1983. Southern Bahian moist forests. Botanical Rev. 49:155-232. http://dx.doi. org/10.1007/BF02861011

MUNHOZ, C.B.R. \& FELFILI, J.M. 2005. Fenologia do estrato herbáceosubarbustivo de uma comunidade de campo sujo na Fazenda Água Limpa no Distrito Federal, Brasil. Acta Bot. Bras. 19(4):979-988. http://dx.doi. org/10.1590/S0102-33062005000400031

MUNIZ, F.H. 2008. Padrões de floração e frutificação de árvores da Amazônia Maranhense. Acta Amaz. 38(4):617-626. http://dx.doi.org/10.1590/ S0044-59672008000400004

NEWSTROM, L.E.F., FRANKIE, G.W. \& BAKER, H.G. 1994. A new classification for plant phenology based on flowering patterns in lowland tropical rain forest trees at La Selva, Costa Rica. Biotropica 26(2):141-159. http://dx.doi.org/10.2307/2388804

PARRINI, R. \& PACHECO, J.F. 2011. Frugivoria por aves em seis espécies arbóreas do gênero Miconia (Melastomataceae) na Mata Atlântica do Parque Nacional da Serra dos Órgãos, Região Sudeste do Brasil. Atual. Ornitol. (159):51-8.

PEDRONI, F., SANCHEZ, M. \& SANTOS, F.A.M. 2002. Fenologia de copaíba (Copaifera langsdorfii Desf. Leguminosae, Caesalpinioideae) em uma floresta semidecídua no sudeste do Brasil. Rev. Bras. Bot. 25:183-194. http://dx.doi.org/10.1590/S0100-84042002000200007

PEREIRA, T.S. \& MANTOVANI, W. 2007 Fenologia reprodutiva de Miconia cinnamomifolia (DC.) Naudin (Melastomataceae), em floresta submontana no Estado do Rio de Janeiro. Rev. Biol. Neotrop. 4(1): 31-45.

PERES, C.A. 2000. Identifying keystone plant resources in tropical forests: the case of gums from Parkia pods. J. Tropical Ecol. 16:287-317. http:// dx.doi.org/10.1017/S0266467400001413

PESSOA, M.S. 2008. Comparação da comunidade arbórea e fenologia reprodutiva de duas fisionomias em Floresta Atlântica no sul da Bahia. Dissertação Mestrado, Universidade Estadual de Santa Cruz, Ilhéus, Bahia.

PIOTTO, D., MONTAGNINI, F., THOMAS, W., ASHTON, M. \& OLIVER, C. 2009. Forest recovery after swidden cultivation across a 40-year chronosequence in the Atlantic forest of southern Bahia, Brazil. Plant Ecol. 205:261-272. http://dx.doi.org/10.1007/s11258-009-9615-2

POULIN, B., WRIGHT, S.J., LEFEBVRE, G. \& CALDERÓN, O. 1999. Interspecific synchrony and asynchrony in the fruiting phenologies of congeneric bird-dispersed plants in Panama. J. Tropical Ecol. 15:213-227. http://dx.doi.org/10.1017/S0266467499000760
RAMOS, F.N. \& SANTOS, F.A.M. 2005. Phenology of Psychotria tenuinervis (Rubiaceae) in Atlantic forest fragments: fragment and habitat scales. Can. J. Bot. 83:1305-1316. http://dx.doi.org/10.1139/b05-106

RENNER, S.S. 1993. Phylogeny and classification of the Melastomataceae and Memecylaceae. Nordic J. Bot. 13:519-540. http://dx.doi. org/10.1111/j.1756-1051.1993.tb00096.x

ROCHA, O.J. \& AGUILAR, G. 2001. Reproductive biology of the dry forest tree Enterolobium cyclocarpum (Guanacaste) in Costa Rica: a comparison between trees left in pastures and trees in continuous forest. Am. J. Bot. 88:1607-1614. PMid:21669694. http://dx.doi.org/10.2307/3558405

ROOS, F.H. \& QUINN, J.A. 1977. Phenology and reproductive allocation in Andropogon scoparius Gramineae) populations in communities of different successional stages. Am. J. Bot. 64:535-540. http://dx.doi. org/10.2307/2442001

SANTOS, A. P.M., ROMERO, R. \& OLIVEIRA, P.E.A.M. 2010. Biologia reprodutiva de Miconia angelana (Melastomataceae), endêmica da Serra da Canastra, Minas Gerais. Rev. Bras. Bot. 33(2):333-341. http://dx.doi. org/10.1590/S0100-84042010000200014

SARMIENTO, G. 1992. Adaptive strategies of perennial grasses in South American savannas. J. Veget. Sci. 3: 325-336. http://dx.doi. org/10.2307/3235757

SATAKE, A., SASAKI, A. \& IWASA, Y. 2001. Variable timing of reproduction in unpredictable environments: adaption of flood plain plants. Theor. Pop. Biol. 60:1-15. PMid:11589635. http://dx.doi.org/10.1006/tpbi.2001.1528

SCHUPP, E.W., HOWE, H.F., AUGSPURGER, C.K. \& LEVEY, D.J. 1989. Arrival and Survival in Tropical Treefall Gaps. Ecology 70:562-564. http://dx.doi.org/10.2307/1940206

SIEMANN, E. \& ROGERS, W.E. 2003. Changes in light and nitrogen availability under pioneer trees may indirectly facilitate tree invasions of grasslands. J. Ecol. 91:923-931. http://dx.doi.org/10.1046/j.13652745.2003.00822.x

SNOW, D.W. 1965. A possible selective factor in the evolution of fruiting seasons in tropical forest. Oikos 15:274-281. http://dx.doi. org/10.2307/3565124

SPINA, A.P., FERREIRA, W.M. \& LEITÃO-FILHO, H.F. 2001. Floração, Frutificação e síndromes de dispersão de uma comunidade de floresta de Brejo na região de Campinas (SP). Acta Bot. Bras. 15(3):349-368. http:// dx.doi.org/10.1590/S0102-33062001000300006

STILES, F.G. \& ROSSELLI, L. 1993. Consumption of fruits of the Melastomataceae by birds: how diffuse is coevolution? Vegetatio 107-108(1):57-73.

THIES, W. \& KALKO, E.K.V. 2004. Phenology of neotropical pepper plants (Piperaceae) and their association with their main dispersers, two shorttailed fruit bats, Carollia perspicillata and C. castanea (Phyllostomidae). Oikos 104:362-376. http://dx.doi.org/10.1111/j.0030-1299.2004.12747.x

VAN SCHAIK, C.P., TERBORGH, J.W. \& WRIGHT, S.J. 1993. The phenology of tropical forests: adaptative significance and consequences for primary consumers. Ann. Rer. Ecol. Syst. 24:353-377. http://dx.doi. org/10.1146/annurev.es.24.110193.002033

WILLIAMS, R.J., MYERS, B.A., EAMUS, D. \& DUFF, G.A. 1999. Reproductive phenology of woody species in a North Australian Tropical savanna. Biotropica 31:626-636. http://dx.doi. org/10.1111/j.1744-7429.1999.tb00411.x

WILLIAMS-LINERA, G. 2003. Temporal and spatial phenological variation of understory shrubs in a tropical montane cloud forest. Biotropica 35(1):28-36.

WRIGHT, S.J. \& VAN SCHAIK, C.P. 1994. Light and the phenology of tropical trees. American Nat. 143:192-199. http://dx.doi.org/10.1086/285600 